\title{
Cymiazole, a systemic acaricide that controls Acarapis woodi (Rennie) infesting honey bees. II. An apiary test ${ }^{\star}$
}

\author{
F. A. Eischen ${ }^{* *}$, D. Cardoso-Tamez ${ }^{2}$, A. Dietz ${ }^{1}$ and G. O. Ware ${ }^{3}$ \\ 1 Department of Entomology, University of Georgia, Athens, GA 30602, USA; \\ 2 Apicultura Cardoso, Apdo. Postal No. 1, Buenavista Allende, Nuevo Leon, Mexico; \\ 3 Agriculture Experiment Station, University of Georgia, Athens, GA 30602, USA
}

(received 1-12-1987, accepted 1-8-1988)

\begin{abstract}
Summary - Honey bee colonies located in northeastern Mexico were grouped according to the prevalence of Acarapis woodi parasitizing their workers. Lightly $(\leq 10 \%)$, moderately $(20-60 \%)$, and heavily $(90-100 \%)$ infested colonies ( $N=30$ each group) were randomly assigned to control or treated subgroups $(N=15)$. Controls received $50 \%$ sucrose syrup, and treated colonies received syrup medicated with $0.3 \mathrm{mg} / \mathrm{ml}$ of cymiazole (2-[2,4-dimethylphenyl-imino]-3-methyl-4-thiazolinehydrochloride, Apitol ${ }^{\circledR}$, GRA, 17.5\% cymiazole, Ciba-Geigy Ltd.). Small, medium, and large colonies received 300,600 , and $1000 \mathrm{ml}$ of syrup, respectively. Syrup was fed 3 times at weekly intervals.

At the end of treatment, the parasite load scores in medicated colonies were $0.53,0.84$, and 0.63 in the lightly, moderately, and heavily infested groups, respectively. This compared with $2.25,3.43$, and 1.13 parasite load scores in the control colonies of the same groups, respectively (all $P<0.05$ ). In each group some colonies did not respond typically to medication. Mite populations at the end of the test were positively associated with colony sizes and food reserves at the beginning of the test. Increased dosages, as well as redistribution/reduction of food reserves are recommended for greater efficacy.

Unexpectedly, medicated colonies had significantly larger bee populations than controls at the end of the test $(P<0.05)$. Increased bee longevity due to parasite load reduction is suggested as the cause.
\end{abstract}

\section{Acarapis woodi-cymiazole - dosage}

Résumé - Le cymiazole (Apitol ${ }^{\circledR}$ ), un acaricide systémique contre Acarapis woodi (Rennie), parasite de l'abeille. II. Test au rucher. On a choisi 3 groupes de colonies d'abeilles ( $\mathrm{N}=30$ ) situées dans le nord-est du Mexique (lat. $25^{\circ} 12^{\prime} \mathrm{N}$, long. $99^{\circ} 58^{\prime} \mathrm{O}$ ) en fonction de leur parasitisme par Acarapis woodi : léger ( $\leq 10 \%)$, moyen (20-60\%), fort (90-100\%). Chaque groupe a été ensuite subdivisé de façon aléatoire en sous-groupes traités et sous-groupes témoins $(\mathrm{N}=15)$. Les témoins ont reçu un sirop de saccharose à $50 \%$ et les colonies traitées un sirop supplémenté avec $0,3 \mathrm{mg} / \mathrm{ml}$ de cymiazole (hydrochlorure de 2-[2,4-diméthylphényl-imino]-3 méthyl-4-thiazoline; spécialité Apitol' ${ }^{B}$ de Ciba-Geigy Ltd. sous forme de granulés dosés à 17,5\% de cymiazole). Les petites colonies, les moyennes et les grosses ont reçu respectivement 300,600 et $1000 \mathrm{ml}$ de sirop 3 fois de suite à une semaine d'intervalle.

\footnotetext{
* Mention of a commercial or proprietary product in this paper does not constitute an endorsement of the product by the University of Georgia or the Food and Drug Administration.

${ }^{*}$ Present address : Department of Entomology, Pullman, WA 99164, USA
} 
A la fin du traitement le taux de parasitisme des colonies traitées était respectivement de 0,53 , 0,84 et 0,63 dans les groupes légèrement, moyennement et fortement infestés, contre 2,25, 3,43 et 1,13 chez les témoins des mêmes groupes $(P<0,05)$. Dans chaque groupe quelques colonies n'ont pas réagi au traitement de façon typique. Les populations d'acariens en fin de test étaient positivement corrélées avec la taille de la colonie et les réserves de nourriture en début de test. Pour une plus grande efficacité, on recommande des doses plus fortes ainsi qu'une redistribution ou une réduction des réserves de nourriture.

Contre toute attente, les colonies traitées avaient en fin de test une population significativement plus forte $(P<0,05)$ que les témoins. On pense que la longévité accrue des abeilles due à la diminution du parasitisme en est la cause.

\section{Acarapis woodi - cymiazole - dosage}

Zusammenfassung - Cymiazol (Apitol $\left.{ }^{\otimes}\right)$, ein sytemisches Akarizid zur Bekämpfung von Acarapis woodi (Rennie) bel Honigbienen. II. Eln Freilandversuch. Drei Gruppen von Völkern der Honigbiene ( $\mathrm{N}=30$ ) in Nordost-Mexiko (lat. $25^{\circ} 12^{\prime} \mathrm{N}$, long. $99^{\circ} 58^{\prime} \mathrm{W}$ ) wurden gemäB ihrem Befall mit Acarapis woodi (Rennie) ausgewähit. Leicht ( $\leq 10 \%)$, mittel $(20-60 \%)$ und stark (90$100 \%)$ befallene Völker wurden anschließend wahllos auf Kontroll- oder Versuchsuntergruppen $(\mathrm{N}=15)$ verteilt. Die Kontrollgruppen erhielten 50\%igen Saccharosesirup, die Versuchsvölker Sirup mit $0.3 \mathrm{mg} / \mathrm{ml}$ Cymiazol (2-[2,4-Dimethylphenyl-imino]-3-methyl-4-thiazolin-hydrochlorid, Apito ${ }^{2}$ $17.5 \%$ Cymiazol Granulat, Ciba-Geigy Ltd.). Die kleinen, mittleren und großen Völker erhielten dreimal 300,600 oder $1000 \mathrm{~m} /$ Sirup in wöchentlichem Abstand.

Nach der Behandlung war die Befallsrate der leicht, mittel und stark befallenen Völker 0.53, 0.84 und 0.64 , im Vergleich zu einer Befallsrate von 2.25, 3.43 und 1.13 bei den Kontrollvölkern der gleichen Gruppe ( $\mathrm{P}<0.05)$. In jeder Gruppe gab es Völker, die nicht typisch auf die Medikation ansprachen. Die Milbenpopulation war am Ende des Versuchs positiv korreliert mit der VolksgröBe und den Futterreserven am Anfang des Tests. Um die Wirksamkeit des Mittels zu erhöhen wird empfohlen, stärker zu dosieren und die Futterreserven umzuverteilen bzw. zu reduzieren.

Entgegen den Erwartungen hatten die behandelten Völker im Vergleich zu den Kontrollvölkern am Ende des Tests eine größere Bienenpopulation ( $\mathrm{P}<0.05)$. Vermutlich ist die Ursache dafür in einer längeren Lebensdauer aufgrund des reduzierten Befallsgrades zu suchen.

\section{Acarapis woodi - Cymiazol - Dosierung}

\section{Introduction}

The rapid spread of the honey bee treacheal mite Acarapis woodi (Rennie) throughout much of Mexico and the United States has complicated and frustrated normal containment procedures (Guzman-Novoa and Zozaya-Rubio, 1984; Anon., 1985; Anon., 1986b). The situation has been exacerbated by its recent discovery in Canada (Anon., 1986c; Gruszka, 1987). A number of Canadian provinces have responded by closing their border to US shipments of queens and package bees (Anon., 1986d). These events left most sectors of North Ameri- can beekeeping in a difficult position. Safe and efficacious control measures would offer relief to infested areas and provide assurance to uninfested regions that this parasite is manageable.

Recently the systemic acaricide cymiazole has been found efficacious in controlling the parasitic honey bee mite, Varroa jacobsoni Oudemans (Ritter, 1985; Schmid, 1985). Additionally, we have found it effective in controlling $A$. woodi in laboratory tests involving caged worker bees (Eischen et al., 1989). This report describes the performance of cymiazole when fed to honey production colonies in Mexico. 


\section{Materials and Methods}

The following terms are used to describe infestations : prevalence $(w)$, the percentage of workers infested within a colony; parasite load, the numbers of mites in an individual bee; parasite load score, an estimate of the parasite load. These terms are in keeping with current parasitological terminology (Margolis et al., 1982).

During early February 1987, 90 colonies of honey bees located near Soto la Marina, Tamaulipas, Mexico (lat. $23^{\circ} 46^{\prime} \mathrm{N}$, long. $98^{\circ}$ 12 W) were selected for testing. Only colonies with a laying queen, brood in all stages, and bees across at least 3 frames were chosen. Colonies were grouped according to the prevalence (w) of infested bees, viz., Group I, $\leq 10 \%$, Group II, 20-60\%, and Group III, 90-100\% $(N=30)$. Infestation levels were determined by removing 20 bees from the inner surface of the hive cover, placing them in $80 \%$ ethyl alcohol and dissecting them according to the technique described by Eischen (1987). Bradbury (1924a, b) has shown that a 20 bee sample gives reasonable accuracy except for the lowest infestations. Colonies were moved on 20 February 1987 to the test site near El Naranjo, Nuevo Leon (lat. $25^{\circ} 12^{\prime} \mathrm{N}$, long. $99^{\circ} 58^{\prime} \mathrm{W}$ ). This location lies in the foothills of the Sierra Madre Oriental and was chosen for its isolation from other managed colonies and distance from citrus orchards. The latter was important because citrus trees in the general region were expectad to flower in late March, and we wished to ensure that the bees would not be diverted from the medicated syrup.

Colonies within infestation groups (I, II and III) were randomly assigned to either medicated or unmedicated subgroups $(N=15)$. Colonies in the 3 untreated subgroups were located $\mathrm{ca}$. $100 \mathrm{~m}$ from the 3 treated subgroups. Distance between subgroups ranged from $10-50 \mathrm{~m}$. Intercolony distance within subgroups was $\approx 2 \mathrm{~m}$. These distances were chosen to reduce intercolony drifting by workers.

A few days prior to treatment, colonies were examined and estimates of the quantities of bees, brood, honey, and pollen made in terms of standard Langstroth frames (Kulinčević et al., 1982). Additionally, a sample of 20 bees was taken from each colony, placed in $80 \%$ ethyl alcohol and subsequently an estimate of their parasite load made, using the techniques described by Eischen (1987).
Based on the number of adult bees, the 5 median colonies of each subgroup were selected for monitoring while the test was being conducted. Ten bees from each of these colonies were removed weekly from the inner surface of the hive cover. Bees were dissected and the number of living and dead mites counted according to the techniques described by Eischen et al. (1987). Our purpose in monitoring these colonies was to determine how selected dosages were affecting mite populations. This information gave us the option of altering the dose if conditions warranted it. However, no changes were made.

Colony treatment began on 28 February. All medicated colonies received syrup containing $0.3 \mathrm{mg} / \mathrm{ml}$ of cymiazole (2-[2,4-dimethylphenylimino]-3-methyl-4-thiazoline hydrochloride, Apitol $^{\circledR}$, GRA, $17.5 \%$ cymiazole, Ciba-Geigy Ltd.). One liter of medicated syrup was prepared by dissolving $1.714 \mathrm{~g}$ of $\mathrm{Apitol}^{\left({ }^{\circledR}\right.}$ in one liter of warm (ca. $30^{\circ} \mathrm{C}$ ) $50 \%$ sucrose syrup (vol/vol).

Enough medicated or unmedicated syrup was prepared to treat one subgroup daily. The quantity of syrup that each colony received was based on the quantity of adult bees. Two small colonies ( 3 frames covered with bees, both in Group III, medicated) received $300 \mathrm{ml}$, medium-sized colonies ( $3-7$ frames) received $600 \mathrm{ml}$, and large colonies (> 7 frames) received $1000 \mathrm{ml}$. Syrup was placed in metal cans $(1600 \mathrm{ml})$ fitted with friction top lids in which several holes had been punched. These cans were inverted and placed over the top bars of the uppermost frames of the colony. Bees normally removed the syrup within $48 \mathrm{~h}$. A few colonies were slower, in which case after $72 \mathrm{~h}$ the remaining syrup was sprinkled over the bees. Colonies were fed 3 times at 7-day intervals. At the end of treatment, a light nectar flow occurred. One standard shallow and one deep super were given to all but the 2 extremely small colonies in Group III, medicated. Twentyfive days later, these supers were weighed. The average of 5 supers of each size were used to tare filled supers. Thirty days after the last feeding, colonies were reexamined and estimates of quantities of bees, brood, honey and pollen made, along with an estimate of the parasite load.

Colony estimates and mite data were evaluated with analysis of covariance (Snedecor and Cochran, 1967). The objective was to determine how the medication affected each infestation group, i.e. Groups I, II, and III. Mean differences between beginning and ending values within each group were tested for signifi- 
cance after adjusting for initial starting treatment subgroup means. Additionally, infestation percentages were given an arcsine transformation.

\section{Results}

One colony died in each of the medicated colonies of Groups II and III. These deaths were from queenlessness and extreme dwindling, respectively, and were not associated with the medication. Data from these colonies have not been included in the analysis. Near the end of the treatment period (15-25 March) several colonies raised varying numbers of queen cells, probably in preparation for swarming. None were found in the colonies of Group III. Approximately $50 \%$ of the medicated colonies in Groups I and II raised queens, while about $30 \%$ of the control colonies of these groups did so. All colonies were examined weekly for queen cells and when found were destroyed. One swarm was found near the Group I control colonies. Medicated colonies took about $24 \mathrm{~h}$ longer to remove their syrup than did controls. We have since learned that Apitol ${ }^{\circledR}$ may have reacted with the metal containers. If so, palatability (but not effectiveness) of treated syrups may have been reduced (W.J. Schmid, pers. comm.).
When initially selected on 7 February 1987 , the percentages of bees parasitized by $A$. woodi in Groups I, II and III averaged $6.0 \pm 1.5,42.4 \pm 3.9$, and $91.8 \pm$ $1.6 \%$, respectively. However, by 28 February when the test began, mite populations in the same groups averaged $21.0 \pm 1.8,47.3 \pm 3.6$, and $76.4 \pm 3.9 \%$, respectively. That is, populations of $A$. woodi had increased in Group I, remained about the same in Group II, and had decreased in Group III. This pattern of change continued during the test period in the untreated controls.

Mite population changes in the 5 median indicator colonies are shown in Figure 1. In general, $\boldsymbol{A}$. woodi populations stabilized or declined in the medicated colonies, while they rose in the untreated colonies. The relative level of control observed in the 5 colonies was indicative of the entire subgroup (see Table I for comparison). Seven days after the last medication (28th day), infestations in the 5 control colonies of Groups I, II and III, averaged 13.9, 15.6 and 10.5 mites/trachea, respectively. Medicated colonies of the same groups at the end of the test had on average 2.5, 8.9 and 5.1 mites in their trachea, respectively.

A. woodi populations at the beginning and end of the test are more completely described by the data presented in Table I. Parasite load scores show that during the test, mite populations rose
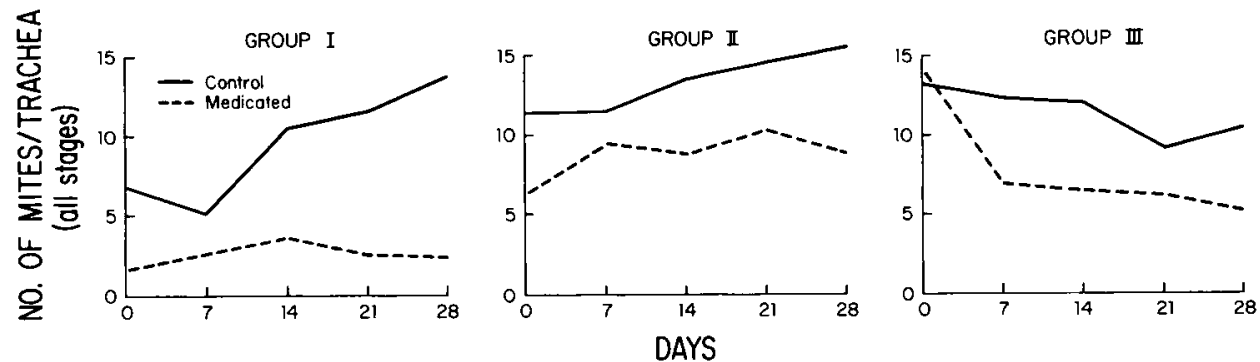

Fig. 1. Survival of Acarapis woodi (all stages) in the 5 indicator colonies treated with cymiazole. Groups I, II and III were lightly, moderately, and heavily infested, respectively. 
Table I. Parasite load scores, colony infestation levels, and percentages of bees harboring bilateral infestations of $A$. woodi in colonies treated with cymiazole.

\begin{tabular}{|c|c|c|c|c|c|}
\hline Group & $\begin{array}{c}28 \text { February }{ }^{1} \\
(\bar{X} \pm S E)\end{array}$ & $\begin{array}{l}28 \text { April } \\
(\bar{X} \pm S E)\end{array}$ & $\begin{array}{c}\text { Observed } \\
\text { difference } \\
\qquad(\bar{X})\end{array}$ & $\begin{array}{c}\text { Adjusted }^{2} \\
\text { difference } \\
\qquad(\bar{X})\end{array}$ & $\%$ Change \\
\hline
\end{tabular}

Parasite load score ${ }^{3}$

$\begin{array}{rlrrrrr}\text { I } & \text { Control4 } & 0.88 \pm 0.12 & 2.25 \pm 0.40 & 1.37 & 1.45 & 255.7 \\ & \text { Treated } & 0.69 \pm 0.11 & 0.53 \pm 0.12 & -0.16 & -0.22 * 5 & 76.8 \\ \text { II } & \text { Control } & 2.50 \pm 0.20 & 3.43 \pm 0.47 & 0.93 & 1.12 & 137.2 \\ & \text { Treated } & 2.13 \pm 0.34 & 0.84 \pm 0.16 & -1.29 & -1.51 * * & 39.4 \\ & & & & & \\ \text { III } & \text { Control } & 5.14 \pm 0.38 & 1.13 \pm 0.23 & -4.01 & -3.60 & 21.9 \\ & \text { Treated } & 4.45 \pm 0.42 & 0.63 \pm 0.19 & -3.82 & -4.28 * & 14.2\end{array}$

\section{Prevalence $(w)^{b}$}

$\begin{array}{llllrrr}\text { I Control } & 29.5 \pm 2.3 & 51.0 \pm 7.6 & 21.5 & 22.4 & 172.9 \\ & \text { Treated } & 23.3 \pm 2.5 * & 21.8 \pm 4.3 & -1.5 & -4.9^{* *} & 93.6 \\ \text { II } & \text { Control } & 47.1 \pm 3.8 & 67.3 \pm 8.6 & 20.2 & 23.3 & 142.9 \\ & \text { Treated } & 39.6 \pm 6.0 & 29.2 \pm 5.4 & -10.4 & -16.3^{* *} & 73.7 \\ & & & & & \\ \text { III } & \text { Control } & 66.8 \pm 4.7 & 40.3 \pm 6.7 & -26.5 & -22.8 & 60.3 \\ & \text { Treated } & 61.7 \pm 6.3 & 26.0 \pm 6.3 & -35.7 & -40.3 * * & 42.1\end{array}$

\section{$\%$ Bilateral infestation}

$\begin{array}{rlrrrrr}\text { I } & \text { Control } & 26.6 \pm 2.1 & 27.0 \pm 6.8 & 0.4 & 3.9 & 101.5 \\ & \text { Treated } & 20.0 \pm 2.5^{*} & 7.6 \pm 0.9 & -12.4 & -16.3^{* *} & 38.0 \\ \text { II } & \text { Control } & 45.1 \pm 3.7 & 46.4 \pm 8.8 & & & \\ & \text { Treated } & 30.0 \pm 0.4^{* *} & 12.6 \pm 1.8 & -17.4 & -28.5 * * & 102.9 \\ & & & & & 42.0 \\ \text { III } & \text { Control } & 63.9 \pm 4.9 & 15.9 \pm 3.9 & -48.0 & -43.8 & 24.9 \\ & \text { Treated } & 56.3 \pm 6.4 & 9.5 \pm 2.4 & -46.8 & -52.8 & 16.9\end{array}$

\footnotetext{
1 The test started on 28 February, and 28 April marked the 30th day after the last treatment.

2 Means were adjusted to a common initial value.

3 Parasite load scores cannot be converted to precise mites/bee, but multiplication by 10 gives a rough approximation. See Eischen (1987) for estimation procedures.

$4 N=15$ for all subgroups, with the exception of II and III-treated, which had 14 colonies.

5 Values followed with an asterisk are significantly different from the value immediately above it (analysis of covariance). ${ }^{*} P<0.05 ;{ }^{* *} P<0.01$.

6 Prevalence $(w)$ is the percentage of infested bees within a colony. These data and the $\%$ bilateral infestations were given an arcsine transformation.
} 
$255.7 \%$ in the control colonies of Group I. Populations in the medicated colonies of this group declined to $76.8 \%$ of their starting numbers $(P<0.01)$. Group II data were similar. Mite populations in control colonies rose $137 \%$, while medicated colonies declined to $39.4 \%$ of their starting population $(P<0.01)$. In contrast, parasite load scores declined in both the control and medicated colonies of Group III. The decline was greatest in the medicated colonies $(P<0.01)$. Though parasite load scores cannot be converted to precise mites/bee, the data indicate that in the control colonies of Groups I, II and III, there were roughly $22.5,34.3$ and 11.3 mites/bee, respectively at the end of the test. Medicated colonies of the same groups had roughly $5.3,8.4$ and 6.3 mites/bee, respectively.

Similar shifts in the mite populations were observed in the prevalence $(w)$ of infested bees. That is, in the untreated colonies of Groups I and II, populations rose to 173 and $143 \%$ respectively, while populations fell in the medicated colonies to 94 and $74 \%$ of their starting values, respectively (both $P<0.01$, Table 1). The number of infested bees in both the control and medicated colonies dropped in Group III, with the decline being greatest in the medicated colonies $(P<0.01)$. The percentage of bees harboring bilateral infestations underwent changes similar to those described above. As with the parasite load score and prevalence (w), the number of bilateral infestions declined in all the treated subgroups. Downward shifts were most pronounced in colonies bearing the heaviest infestations (Table I).

During the test, colony size, i.e. number of adult bees, increased in all treatment groups (Table II). Medicated colonies attained a greater size than controls in all groups and were significantly larger in Groups II $(P<0.05)$ and III $(P<0.01)$. The percent increase in colony size was greatest in Group III. This may reflect the increased reproductive efficiency of smaller colonies (Michener, 1964; Eischen et al., 1983).

No significant differences were observed in brood production between control and medicated colonies (Table II). The quantity of honey in medicated and control colonies did not differ significantly at the start of the test or after the surplus honey was harvested (Table II). Medicated colonies and greater pollen stores than did controls. Differences were significant for Groups I and II (both $P<0.05$ ). Honey production during the light nectar flow by control colonies averaged 9.9, 8.7, and $4.3 \mathrm{~kg}$ for Groups I, II and III, respectively. Medicated colonies of the same groups produced 12.6, 7.7 and $5.2 \mathrm{~kg}$, respectively. These differences were not significant. Though medicated colonies had significantly more bees, more of them attempted to swarm. This may have reduced honey production.

At the beginning of the test, parasite load scores were negatively correlated with the quantity of bees $(r=-0.54$, $P<0.01)$, brood $(r=-0.48, P<0.01)$, honey $(r=-0.23, P<0.05)$, and pollen $(r=-0.29, P<0.01$; Table III). Similar but smaller correlation coefficients were found for both the prevalence $(w)$ of infested bees, and the percentages of bees that were bilaterally infested (Table III). The smaller $r$-values for these measures probably reflect a less accurate estimate of the parasite loads.

In an attempt to identify factors affecting the performance of cymiazole, correlations were calculated between colony populations at the start of the test with those found 30 days after the last treatment. In control colonies, ending parasite load scores in Group II were positively correlated with the quantities of bees and brood and at the beginning of the test 
Table II. Quantities of bees, brood, honey, and pollen in colonies medicated with cymiazole 1.

\begin{tabular}{|c|c|c|c|c|c|c|}
\hline \multicolumn{2}{|c|}{ Group } & $\begin{array}{c}28 \text { February }{ }^{2} \\
(X \pm S E)\end{array}$ & $\begin{array}{l}28 \text { April } \\
(X \pm S E)\end{array}$ & $\begin{array}{l}\text { Observed } \\
\text { difference } \\
\qquad(X)\end{array}$ & $\begin{array}{l}\text { Adjusted } 3 \\
\text { difference } \\
\qquad(X)\end{array}$ & $\%$ Change \\
\hline \multicolumn{7}{|c|}{ Bees } \\
\hline 1 & $\begin{array}{l}\text { Control } 4 \\
\text { Treated }\end{array}$ & $\begin{array}{l}7.2 \pm 0.8 \\
6.6 \pm 0.3\end{array}$ & $\begin{array}{l}10.7 \pm 1.1 \\
11.3 \pm 0.8\end{array}$ & $\begin{array}{l}3.55 \\
4.65\end{array}$ & $\begin{array}{l}3.51 \\
4.43\end{array}$ & $\begin{array}{l}150.0 \\
171.2\end{array}$ \\
\hline ॥ & $\begin{array}{l}\text { Control } \\
\text { Treated }\end{array}$ & $\begin{array}{l}6.8 \pm 0.5 \\
7.1 \pm 0.7\end{array}$ & $\begin{array}{r}9.4 \pm 0.8 \\
12.2 \pm 0.8\end{array}$ & $\begin{array}{l}2.64 \\
5.23\end{array}$ & $\begin{array}{l}2.63 \\
5.34\end{array}$ & $\begin{array}{l}138.2 \\
171.8\end{array}$ \\
\hline III & $\begin{array}{l}\text { Control } \\
\text { Treated }\end{array}$ & $\begin{array}{l}4.0 \pm 0.3 \\
3.7 \pm 0.6\end{array}$ & $\begin{array}{r}9.0 \pm 0.7 \\
11.9 \pm 1.1\end{array}$ & $\begin{array}{l}5.07 \\
7.91\end{array}$ & $\begin{array}{l}5.07 \\
7.91\end{array}$ & $\begin{array}{l}225.0 \\
321.6\end{array}$ \\
\hline \multicolumn{7}{|c|}{ Brood } \\
\hline 1 & $\begin{array}{l}\text { Control } \\
\text { Treated }\end{array}$ & $\begin{array}{l}4.6 \pm 0.4 \\
4.8 \pm 0.3\end{array}$ & $\begin{array}{l}6.9 \pm 0.7 \\
6.6 \pm 0.4\end{array}$ & $\begin{array}{l}2.37 \\
1.81\end{array}$ & $\begin{array}{l}2.38 \\
1.89\end{array}$ & $\begin{array}{l}152.2 \\
137.5\end{array}$ \\
\hline$\|$ & $\begin{array}{l}\text { Control } \\
\text { Treated }\end{array}$ & $\begin{array}{l}4.2 \pm 0.3 \\
5.2 \pm 0.6\end{array}$ & $\begin{array}{l}6.1 \pm 0.7 \\
7.2 \pm 0.5\end{array}$ & $\begin{array}{l}1.88 \\
2.29\end{array}$ & $\begin{array}{l}1.58 \\
2.46\end{array}$ & $\begin{array}{l}142.9 \\
138.5\end{array}$ \\
\hline III & $\begin{array}{l}\text { Control } \\
\text { Treated }\end{array}$ & $\begin{array}{l}3.1 \pm 0.2 \\
2.8 \pm 0.5\end{array}$ & $\begin{array}{l}6.4 \pm 0.4 \\
6.5 \pm 0.5\end{array}$ & $\begin{array}{l}3.31 \\
3.51\end{array}$ & $\begin{array}{l}3.33 \\
3.48\end{array}$ & $\begin{array}{l}206.5 \\
232.1\end{array}$ \\
\hline \multicolumn{7}{|c|}{ Honey 5} \\
\hline I & $\begin{array}{l}\text { Control } \\
\text { Treated }\end{array}$ & $\begin{array}{l}4.3 \pm 0.8 \\
5.0 \pm 0.6\end{array}$ & $\begin{array}{l}3.2 \pm 0.5 \\
3.1 \pm 0.4\end{array}$ & $\begin{array}{l}-1.05 \\
-1.99\end{array}$ & $\begin{array}{l}-1.38 \\
-1.65\end{array}$ & $\begin{array}{l}74.4 \\
62.0\end{array}$ \\
\hline II & $\begin{array}{l}\text { Control } \\
\text { Treated }\end{array}$ & $\begin{array}{l}5.1 \pm 0.8 \\
3.5 \pm 0.4\end{array}$ & $\begin{array}{l}3.4 \pm 0.5 \\
2.6 \pm 0.3\end{array}$ & $\begin{array}{l}-1.73 \\
-1.05\end{array}$ & $\begin{array}{l}-1.34 \\
-1.59\end{array}$ & $\begin{array}{l}66.7 \\
74.3\end{array}$ \\
\hline III & $\begin{array}{l}\text { Control } \\
\text { Treated }\end{array}$ & $\begin{array}{l}3.6 \pm 0.3 \\
3.2 \pm 0.5\end{array}$ & $\begin{array}{l}3.1 \pm 0.3 \\
3.1 \pm 0.4\end{array}$ & $\begin{array}{l}-0.47 \\
-0.31\end{array}$ & $\begin{array}{l}-0.39 \\
-0.37\end{array}$ & $\begin{array}{l}86.1 \\
96.9\end{array}$ \\
\hline \multicolumn{7}{|c|}{ Pollen } \\
\hline I & $\begin{array}{l}\text { Control } \\
\text { Treated }\end{array}$ & $\begin{array}{l}0.6 \pm 0.1 \\
0.2 \pm 0.1\end{array}$ & $\begin{array}{l}2.0 \pm 0.4 \\
2.0 \pm 0.2\end{array}$ & $\begin{array}{l}1.41 \\
1.85\end{array}$ & $\begin{array}{l}1.02 \\
1.93\end{array}$ & $\begin{array}{r}333 \\
1000\end{array}$ \\
\hline II & $\begin{array}{l}\text { Control } \\
\text { Treated }\end{array}$ & $\begin{array}{l}0.5 \pm 0.1 \\
0.4 \pm 0.1\end{array}$ & $\begin{array}{l}1.3 \pm 0.3 \\
2.0 \pm 0.4\end{array}$ & $\begin{array}{l}0.77 \\
1.52\end{array}$ & $\begin{array}{l}0.73 \\
1.57^{*}\end{array}$ & $\begin{array}{l}260 \\
500\end{array}$ \\
\hline III & $\begin{array}{l}\text { Control } \\
\text { Treated }\end{array}$ & $\begin{array}{c}0.1 \pm 0.03 \\
0.2 \pm 0.1\end{array}$ & $\begin{array}{l}1.3 \pm 0.2 \\
1.6 \pm 0.4\end{array}$ & $\begin{array}{l}1.21 \\
1.41\end{array}$ & $\begin{array}{l}0.93 \\
1.37\end{array}$ & $\begin{array}{r}1300 \\
800\end{array}$ \\
\hline
\end{tabular}

\footnotetext{
1 Measurements are in standard Langstroth frames.

2 The test was started on 28 February, and 28 April marked the 30 th day after the last treatment.

3 Means were adjusted to a common initial value (by means of analysis of covariance).

$4 N=15$ for all subgroups except II and III-treated, which had 14 colonies.

5 Surplus honey was removed prior to 28 April. See Table III. ${ }^{\star} P<0.05$; ${ }^{\star \star} P<0.01$.
} 
Table III. Correlation coefficients between colony size and $A$. woodi infestation at the beginning of the test 1 .

\begin{tabular}{|c|c|c|c|c|c|c|c|}
\hline Measurement & Bees & Brood & Honey & Pollen & $\begin{array}{c}\text { Parasite } \\
\text { load } \\
\text { score }\end{array}$ & $\begin{array}{c}\text { Infestation } \\
\text { (\%) }\end{array}$ & $\begin{array}{c}\text { Bilateral } \\
\text { Infestation } \\
(\%)\end{array}$ \\
\hline Bees & 1.00 & $0.88^{\star *}$ & $0.43^{* *}$ & $0.53^{* *}$ & $-0.54 * *$ & $-0.47^{\star \star}$ & $-0.47^{\star \star}$ \\
\hline Brood & & 1.00 & $0.37^{* *}$ & $0.38 * *$ & $-0.48^{* *}$ & $-0.43^{* *}$ & $-0.44^{* *}$ \\
\hline Honey & & & 1.00 & $0.35^{* \star}$ & $-0.23^{\star}$ & -0.20 & -0.15 \\
\hline Pollen & & & & 1.00 & $-0.29^{\star *}$ & $-0.22 *$ & -0.20 \\
\hline \multicolumn{2}{|c|}{ Parasite load score } & & & & 1.00 & $0.97^{* *}$ & $0.95^{* *}$ \\
\hline$\%$ Infestation & & & & & & 1.00 & 0.96 ** \\
\hline \multicolumn{2}{|c|}{$\%$ Bilateral infestation } & & & & & & 1.00 \\
\hline
\end{tabular}

$1 N=88$ colonies.

$*{ }^{*} P<0.05 ; * * P<0.01$.

$(P<0.05$, Table IV). Similar correlations were found for medicated colonies in Groups II and III $(P<0.05$, Table V). Initial quantities of honey and pollen were positively correlated with ending parasite load scores in Group III $(P<0.05)$. A negative correlation was found between the initial and ending parasite loads of medicated colonies $(P<0.01)$.

\section{Discussion}

Medication with cymiazole resulted in significant mite reduction. The level of control achieved was about the same in the 3 infestation groups. In each group $\approx$ $20 \%$ of the colonies did not respond typically to the medication. Why this occured is not clear. A series of correlations was made in an attempt to identify associated factors. In general, larger colonies had higher parasite levels, suggesting that more medicated syrup should have been fed. Additionally, colonies with larger honey reserves at the beginning of the test had higher ending mite populations. Perhaps not needing the additional food, the medicated syrup was only stored (Moritz, 1982). This suggests that honey reserves may need to be redistributed or even reduced before treating. Should this be imprudent, a topical application could be employed (Anon., 1986a).

The rather dramatic mite population changes in the control colonies affected the efficacy estimates. Mite populations expanded in both the lightly and moderately infested colonies, but dropped in the heavily infested colonies. Eischen et al. (1989) observed similar shifts during late winter-early spring. The drop in heavily infested colonies has been attributed to the differential mortality of severely parasitized worker bees (Eischen et al., 1989). A. woodi populations dropped in all medi- 
Table IV. Correlation coefficients between beginning and ending measurements made on colonies treated with cymiazole : control colonies ${ }^{1}$.

\begin{tabular}{lcccc}
\hline Measurement & Bees ${ }^{2}$ & Brood & Pollen & $\begin{array}{c}\text { Parasite } \\
\text { load score }\end{array}$ \\
\hline Group /3 & & & & \\
Bees 4 & $0.81^{* *}$ & $0.47^{* *}$ & $0.66^{* *}$ & 0.15 \\
Brood & $0.73^{* *}$ & $0.68^{* *}$ & 0.40 & 0.32 \\
Honey & $0.65^{* *}$ & 0.41 & 0.18 & 0.32 \\
Pollen & $0.56^{* *}$ & 0.37 & 0.03 & 0.26 \\
Parasite load score & 0.17 & 0.01 & -0.14 & 0.06 \\
& & & & \\
Group II & & & & $0.65^{* *}$ \\
Bees & 0.29 & 0.05 & -0.07 & $0.566^{*}$ \\
Brood & 0.18 & 0.06 & -0.09 & 0.29 \\
Honey & 0.42 & 0.16 & -0.05 & 0.28 \\
Pollen & 0.09 & -0.01 & $0.50 \$$ & -0.02 \\
Parasite load score & 0.37 & 0.22 & 0.15 & \\
& & & & 0.15 \\
Group III & & & & 0.37 \\
Bees & 0.40 & $0.49 \$$ & -0.19 & -0.07 \\
Brood & 0.32 & 0.46 & -0.24 & 0.08 \\
Honey & -0.21 & 0.01 & -0.36 & -0.37 \\
Pollen & 0.28 & 0.05 & -0.30 & \\
Parasite load score & 0.02 & -0.19 & 0.28 & \\
\hline
\end{tabular}

$1 N=15$ for each group.

2 Measurements made 30 days subsequent to last treatment. Values for honey are not given, as it was harvested prior to colony evaluation.

3 Groups I, II and III were lightly, moderately, and heavily infested with $A$. woodi, respectively.

4 Measurements made prior to first treatment.

$\S P<0.07 ; * P<0.05 ;{ }^{* *} P<0.01$.

cated colonies. Differences between treated and control colonies were largest in the moderately infested colonies and smallest in those that were heavily infested. That is, cymiazole was most effective in moderately infested colonies and least effective in heavily infested ones. Why heavily infested colonies should be less responsive is not clear. Perhaps differential mortality of heavily infested workers simply obscured cymiazole's potential efficacy. If this is true, it may be advantageous to medicate infested colonies in autumn, thereby reducing spring mortality.

Unexpectedly, treatment with cymiazole was associated with significant increases in bee populations. Ending brood nest sizes were not different, suggesting that cymiazole promoted longevity in bees. This could have been effected by alleviating the stress of the parasite load or by the lengthening life in a more direct way. Eischen (1987) also observed that infested colonies medicated with oxytetracycline $\mathrm{HCl}$ and fumagillin in autumn had larger overwintering bee populations.

In summary, the level of control achieved, while not complete, did reduce $A$. woodi populations to at or below the suspected economic threshold, viz. $30 \%$ of bees infested (Bailey, 1961; Eischen, 1987; Eischen et al., 1989). Based on these observations and others (Dietz et al., unpublished) we believe colony 
Table V. Correlation coefficients between beginning and ending measurements made on colonies treated with cymiazole : medicated colonies ${ }^{1}$.

\begin{tabular}{|c|c|c|c|c|}
\hline Measurement & Bees $^{2}$ & Brood & Pollen & $\begin{array}{l}\text { Parasite }{ }^{3} \\
\text { load score }\end{array}$ \\
\hline \multicolumn{5}{|l|}{ Group / 4} \\
\hline Bees $^{5}$ & 0.05 & 0.25 & -0.06 & 0.06 \\
\hline Brood & 0.06 & 0.21 & -0.02 & -0.06 \\
\hline Honey & 0.45 & 0.58 * & 0.11 & 0.01 \\
\hline Poilen & 0.16 & -0.05 & 0.42 & -0.10 \\
\hline Parasite load score & 0.15 & -0.03 & 0.63 * & 0.31 \\
\hline \multicolumn{5}{|l|}{ Group // } \\
\hline Bees & $0.57^{*}$ & $0.66^{*}$ & 0.29 & $0.76^{* *}$ \\
\hline Brood & 0.50 * & $0.60^{*}$ & 0.24 & 0.69 ** \\
\hline Honey & 0.15 & -0.12 & 0.16 & -0.01 \\
\hline Pollen & $0.50^{*}$ & -0.15 & $0.60^{*}$ & 0.22 \\
\hline Parasite load score & -0.05 & -0.04 & -0.34 & -0.38 \\
\hline \multicolumn{5}{|l|}{ Group III } \\
\hline Bees & $0.88^{* *}$ & $0.78^{* *}$ & $0.74 * *$ & $0.54 *$ \\
\hline Brood & $0.89^{\text {** }}$ & 0.81 ** & $0.77^{\star *}$ & $0.49 \S$ \\
\hline Honey & 0.23 & 0.09 & 0.13 & $0.73^{* *}$ \\
\hline Pollen & 0.41 & 0.31 & 0.33 & 0.59 * \\
\hline Parasite load score & -0.19 & -0.30 & -0.01 & $-0.73^{\star \star}$ \\
\hline
\end{tabular}

+ $N=15$ for Group I. $N=14$ for Groups II and III.

2 Measurements made 30 days subsequent to last treatment. Values for honey are not given, as it was harvested prior to colony evaluation.

${ }^{3}$ An estimate of the parasite load. Similar correlations were found for prevalence $(w)$ and the percent of workers bilaterally infested.

4 Groups I, II and III were lightly, moderately, and heavily infested with A. woodi, respectively.

5 Measurement made prior to first treatment.

\& $P<0.07 ; * P<0.05 ;{ }^{* *} P<0.01$.

dosages could be raised $20-25 \%$ without risk. This could probably be best accomplished by raising the concentration of cymiazole, along with somewhat greater quantities of syrup, especially for larger colonies. Application times and techniques that foster consumption of treated syrups should also enhance efficacy.

\section{Acknowledgments}

We wish to thank W.G. Hart, USDA-ARS Subtropical insects Laboratory, W.T. Wilson, USDA-ARS Honey Bee Laboratory, and $\mathrm{H}$. Shi- manuki, USDA-ARS Beneficial Insects Laboratory, for advice and assistance while in Mexico. Dorset Hurley provided technical assistance. We are also grateful to the staff and families of Apicultura Cardoso, who provided a great deal of assistance as well as making our stay in Mexico informative and memorable. Special thanks are due to W.J. Schmid, Ciba-Geigy Switzerland, who arranged for financial support through Research Grant 25-21-RC293-108.

\section{References}

Anon. (1985) APHIS to propose federal mite regulations be dropped. Speedy Bee 14 (9), p. 2 
Anon. (1986a) Apitol-readily available food for bees. Bienenstich 8, p. 7

Anon. (1986b) Mite programs are under fire. Speedy Bee 15 (1), 1-2

Anon. (1986c) Manitoba quarantines tracheal mite infested colonies. Am. Bee. J. 126, 589

Anon. (1986d) East Canada closed to US bee shipments. Speedy Bee 15 (3), p. 1

Bailey L. (1961) The natural incidence of ACarapis woodi (Rennie) and the winter mortality of honey bee colonies. Bee World 42, 96-100

Bradbury F.C.S. (1924a) Some calculations on acarine disease. Bee World 5, 145-147

Bradbury F.C.S. (1924b) Further calculations on acarine disease. Bee World 6, 50-51

Eischen F.A. (1987) Overwintering performance of honey bee colonies heavily infested with Acarapis woodi (Rennie). Apidologie 18, 293-304

Eischen F.A., Cardoso-Tamez D., Wilson W.T. \& Dietz A. (1989) Honey production of honey bee colonies infested with Acarapis woodi (Rennie). Apidologie 20, 1-8

Eischen F.A., Pettis J.S. \& Dietz A. (1987) A rapid method of evaluating compounds for the control of Acarapis woodi (Rennie). Am. Bee J. 127, 99-101

Eischen F.A., Rothenbuhler W.C. \& Kulinčević J.M. (1983) Brood rearing associated with a range of worker-larva ratios in the honey bee. J. Apic. Res. 22, 163-168

Eischen F.A., Vergara C., Dietz A. \& CardosoTamez D. (1988) Cymiazole, a systemic acaricide for the control of Acarapis woodi (Rennie) infesting honey bees. I. Laboratory tests. Apidologie 19, 367-385

Gruszka J. (1987) Honey bee tracheal mites : are they harmful ? Am. Bee J. 127, p. 653

Guzman-Novoa E. \& Zozaya-Rubio A. (1984) The effects of chemotherapy on the level of infestation and production of honey in colonies of honey bees with acariosis. Am. Bee J. 124, 669-672

Kulinčević J.M., Rothenbuhler W.C. \& Rinderer T.E. (1982) Disappearing disease. I. Effects of certain protein sources given to honey-bee colonies in Florida. Am. Bee J. 122, 189-191

Margolis L., Anderson R.C. and Holmes J.C. (1982) Recommended usage of selected terms in ecological and epidemiological parasitology. Bull. Can. Soc. Zool. 13, p. 14

Michener C.D. (1964) Reproductive efficiency in relation to colony size in hymenopterous societies. Insectes Soc. 11, 317-341

Moritz R.F.A. (1982) Präparatverteilung bei systemischer Therapie von Ektoparasitosen bei Apis mellifera L. Apidologie 13, 127-141

Ritter W. (1985) First results from biological trials with Apitol, a medicament with systemic activity. Proc. 30th Int. Apic. Congr., Nagoya, Japan

Schmid W.J. (1985) Apitol $\left.{ }^{(}\right)$a new acaricide with systemic activity against Varroa mites. Proc. 30th int. Apic. Congr., Nagoya, Japan

Snedecor G.W. \& Cochran W.G. (1967) Statistical Methods. The lowa State University Press, Ames, lowa, pp. 593 